\title{
FOLK-TALE NETWORKS: A STATISTICAL APPROACH TO COMBINATIONS OF TALE TYPES*
}

\author{
JULIEN D'HUY \\ PhD reseacher \\ African Worlds Institute (IMAF) \\ Centre Malher 9, rue Malher \\ 75004 Paris, France \\ e-mail: dhuy.julien@yahoo.fr
}

\begin{abstract}
This paper is an attempt to study combinations of tale types using a networks approach and calculating the centrality index of each type (degree, betweenness, eigenvector centrality). The network of tale types seems to take the form of a 'small world' with a few types serving as bridges between highly connected sets of tale types. The centrality of each type also seems to depend more on its age than on how widespread it is.
\end{abstract}

KEYWORDS: tales of magic $\bullet$ tale types $\bullet$ combinations $\bullet$ network $\bullet$ centrality

\section{N T RODUCTION}

A tale type is a particular narrative schema in which episodes and narrative motifs are organised in a sufficiently stable way. It is above all a tool for classifying and studying oral transmission stories, i.e. in the Aarne-Thompson-Uther (ATU) classification. The tale type system is very useful for thinking about folk tales in general because it allows structure where diversity would otherwise only be apparent. Yet folk tales are rarely pure and rarely belong to a clearly determined type. The folklorist FrançoisMarie Luzel (1887: 418) said:

I have reproduced these [i.e. the stories] exactly as I have collected them, in order to give an idea of the way certain storytellers, believing to increase the interest of their tales, modify and mix them, to please the listeners. The more a tale is long and filled with marvels and tests, and the more it has of success, usually, to the public of the winter evenings. The longer the tale and the more it is filled with marvels and tests, the more successful it usually is at the audience of winter evenings.

\footnotetext{
* The author thanks the reviewers for their constructive comments which greatly contributed to improving this paper, as well as the editorial team of the Journal of Ethnology and Folkloristics for their invaluable work during the editing process.
} 
According to Lutz Röhrich (1976: 291), "contamination is the essence of popular poetry". For Vladimir Propp (1928: 14-15), "fairy tales have one particularity: the parts of a story can be transported without any change in another story". The importance of contamination in the transmission of tales has been widely studied, and the curious reader can be referred to various articles in the Enzyklopädie des Märchens, including "Affinität" (Voigt 1977), "Assoziation" (Fisher and Lüthi 1977) and "Kontamination" (Shojaei Kawan 1996). So it could be useful to analyse the importance that each instance of storytelling has in the construction of other instances, and how folk tales interact with each other.

Many questions arise: is the interaction between these folk tales random? Are there any rules governing of the networks thus formed? If rules exist, can they be expressed mathematically? And if so, what do they tell us about the establishment of our oral folklore? Although this word is the basis of our analysis, it is difficult to precisely define the notion of combinations of folk tales and so we will use Hans-Jörg Uther's definition (2011: 12-13): under the rubric "Combinations", he lists "the most important of the tales that belong to narrative cycles, or form combinations and contaminations". The representation of such combinations can take the form of a collection of tale types potentially interacting as a system; these types would be the vertices of the network and would be linked into a whole web by undirected edges that would be combinations of interacting folk tales. The network approach to studying human phenomena is not new, for example the study of social networks, including among characters in narratives (for example Mac Carron and Kenna 2012) or the study of the evolution of particular folk tale networks (Karsdorp and van den Bosch 2016; d'Huy 2018).

The ATU classification system has been used to identify folk narratives through tale type numbers and their combinations. In what follows I use a category of folk tales named 'tales of magic' (Uther 2011; ATU 300-794A) to construct a network; such tales are plotted by beings and/or objects with supernatural power.

\section{A T E R I A L}

The most frequent combinations of each tale type with others have been obtained empirically using the work of Uther, who only listed combinations that occur in at least three examples, those with at least eight examples being listed first. This makes it possible to minimise the risks associated with categorising versions: for instance, a version C misclassified as a tale type A combined with a tale type B is not enough to bias the connection between $\mathrm{A}, \mathrm{B}$ and $\mathrm{C}$ for the entire tale type. It should be noted that nonEuropean traditions are severely under-represented in this database (as Uther himself acknowledges) and that our results are only completely valid in Western Eurasia.

To avoid sample bias, high (eight examples at least) and low levels (less than eight examples) of combination between two types have been analysed together and all nodes have been treated as identical: indeed, the boundary between seven and eight combinations depends on factors too random to be valid. Only tale types with interactions were selected. In the final dataset, each tale type was linked to an average of 4.0613 other tale types. 


\section{Network Construction}

The matrix of connected tale types was analysed using Social Network Visualizer v.2.3. (Kalamaras 2017; matrix: adjacency). Many centrality measures (Degree Centrality; Eigenvector Centrality; Betweeness Centrality) were used to address the question, "what is the most central ATU tale type in the studied network?" and to quantify the 'importance' or 'influence' of each ATU tale type. Each measure is based on different assumptions, rather than the classical two-dimensional presentation of the database. In order to make the results readable as widely as possible, two graphical representations showing the same results were always used. The ATU tale types corresponding to the numbers are given in Appendix 1.

The Degree of Centrality (DC) is the sum of edges attached to a node, i.e. in the current paper the number of direct relations of a tale type with others. DC is a standardised index $(0 \leq \mathrm{DC} \leq 1)$. An ATU tale type with a high score is often a node highly connected in the network, yet a large number of the relations could be with low level entities (Table 1; Figures 1a and 1b). The mean DC is 0.042 (variance $=0.001$ ) with 23 classes. This measure is the most objectively representative of the database.

Table 1. ATU tale types with highest Degree of Centrality.

\begin{tabular}{|c|c|c|c|}
\hline Node & Label & DC & $\mathrm{DC}^{\prime}$ \\
\hline 16 & ATU 313 The Magic Flight & 32.000 & 0.198 \\
\hline 17 & $\begin{array}{l}\text { ATU } 314 \text { Goldener (previously The Youth Transformed into a } \\
\text { Horse) }\end{array}$ & 31.000 & 0.191 \\
\hline 1 & ATU 300 The Dragon Slayer & 30.000 & 0.185 \\
\hline 47 & ATU 400 The Man on a Quest for His Lost Wife & 28.000 & 0.173 \\
\hline 4 & ATU 302 The Ogre's (Devil's) Heart in the Egg & 27.000 & 0.167 \\
\hline 103 & $\begin{array}{l}\text { ATU } 531 \text { The Clever Horse (previously Ferdinand the True and } \\
\text { Ferdinand the False). This miscellaneous type comprises various } \\
\text { tales dealing with a clever horse. }\end{array}$ & 24.000 & 0.148 \\
\hline 3 & ATU 301 The Three Stolen Princesses & 21.000 & 0.130 \\
\hline 111 & ATU 554 The Grateful Animals & 21.000 & 0.130 \\
\hline 108 & $\begin{array}{l}\text { ATU } 550 \text { Bird, Horse and Princess (previously Search for the } \\
\text { Golden Bird) }\end{array}$ & 19.000 & 0.117 \\
\hline 57 & $\begin{array}{l}\text { ATU } 425 \text { The Search for the Lost Husband. This type refers to a } \\
\text { cycle of related tales. }\end{array}$ & 19.000 & 0.117 \\
\hline
\end{tabular}




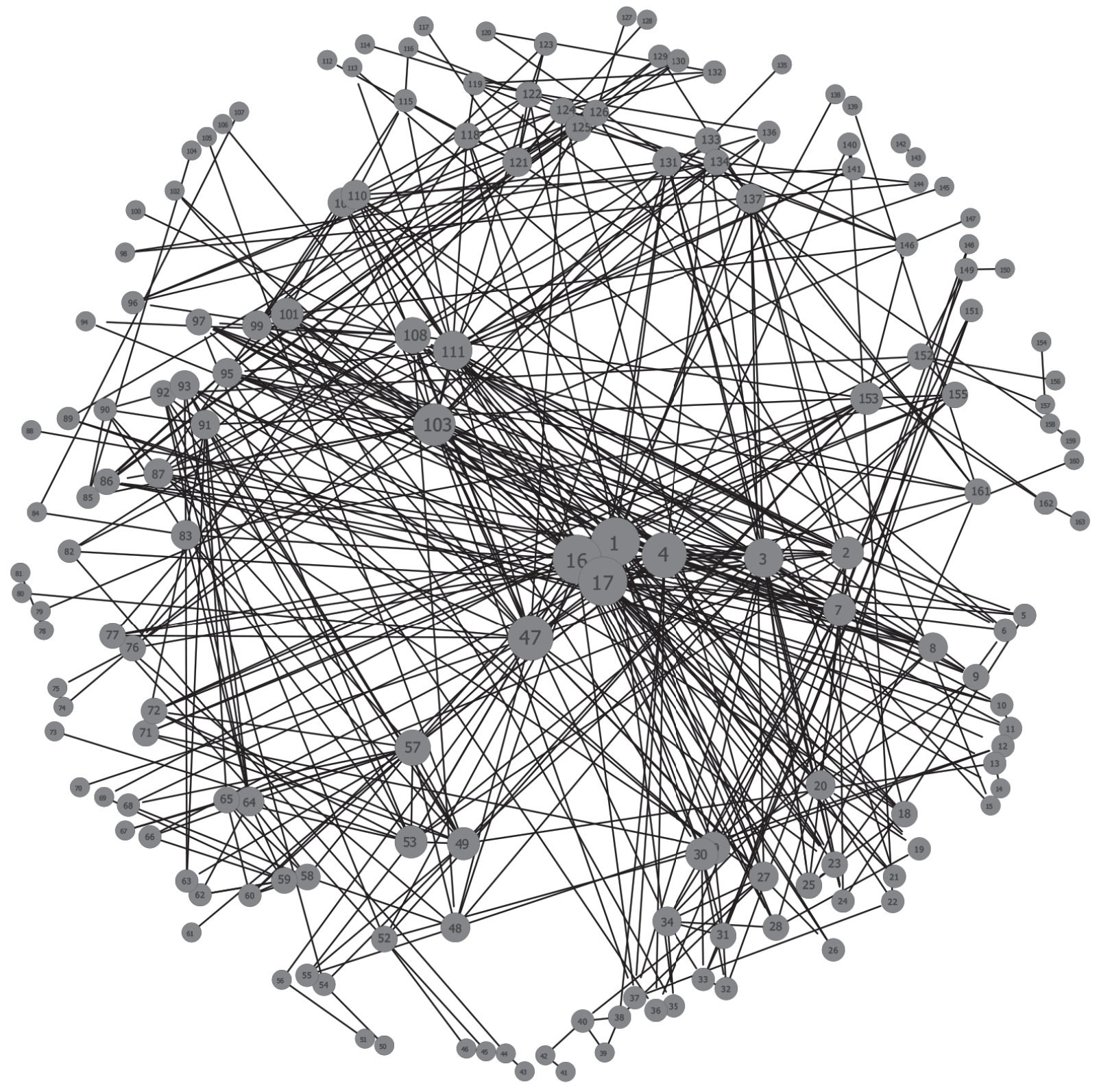

Figures 1a and 1b. Radial ( $a$ ) and on levels (b) by Degree of Centrality. In order to make the results readable as widely as possible, two graphical representations showing the same results were always used. The meaning of both representations is exactly the same. ${ }^{1}$ 


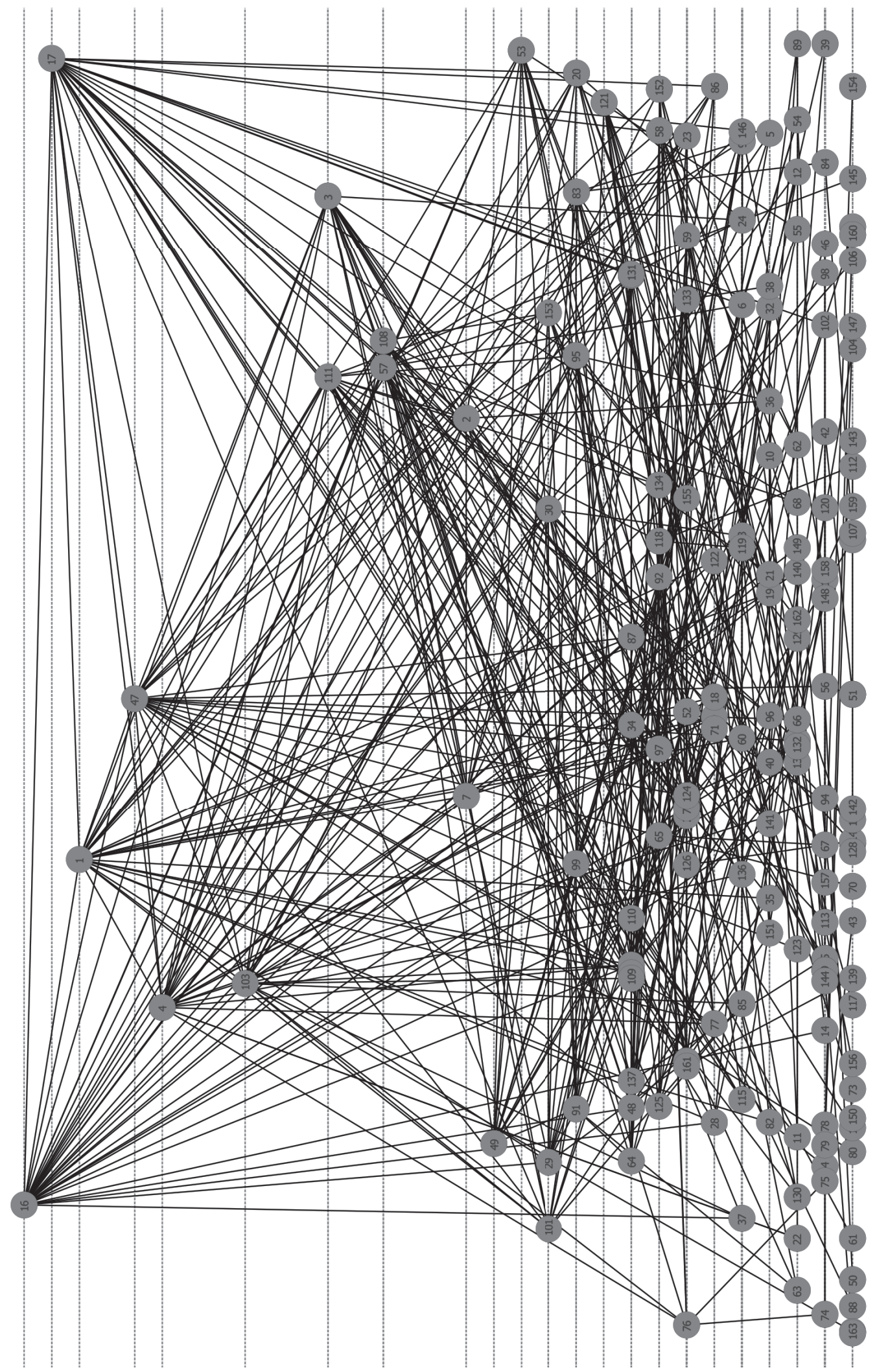


The Eigenvector Centrality or EVC (see Bonacich 1972; standardised index: $0 \leq \mathrm{EVC}^{\prime \prime}$ $<1$ ) is an extension of the simpler DC because it assigns a score proportional to the scores of its neighbours to all nodes. As for the DC method, EVC takes account the number of connections that every tale type has. With this method, high scoring nodes contribute more to the score than equal connections to low scoring nodes (Table 2; Figures $2 \mathrm{a}$ and $2 \mathrm{~b}$ ). The mean EVC is 0.046 (variance $=0.004$ ). By comparing DC and EVC one can make a difference between tale type properties of a) combinations only (DC) and b) combinations with tale types which themselves have higher numbers of combinations (EVC). EVC makes it possible to highlight the most central of the most central tale types.

Table 2. ATU tale types with highest Eigenvector Centrality.

\begin{tabular}{|c|c|c|c|c|}
\hline Node & Label & EVC & $\mathrm{EVC}^{\prime}$ & $\mathrm{EVC}^{\prime \prime}$ \\
\hline 1 & ATU 300 The Dragon Slayer & 0.307 & 1.000 & 0.040 \\
\hline 17 & $\begin{array}{l}\text { ATU } 314 \text { Goldener (previously The Youth Transformed } \\
\text { into a Horse) }\end{array}$ & 0.299 & 0.973 & 0.039 \\
\hline 16 & ATU 313 The Magic Flight & 0.272 & 0.886 & 0.036 \\
\hline 4 & ATU 302 The Ogre's (Devil's) Heart in the Egg & 0.266 & 0.866 & 0.035 \\
\hline 47 & ATU 400 The Man on a Quest for His Lost Wife & 0.262 & 0.852 & 0.035 \\
\hline 103 & $\begin{array}{l}\text { ATU } 531 \text { The Clever Horse (previously Ferdinand the } \\
\text { True and Ferdinand the False). This miscellaneous } \\
\text { type comprises various tales dealing with a clever } \\
\text { horse. }\end{array}$ & 0.236 & 0.770 & 0.031 \\
\hline 3 & ATU 301 The Three Stolen Princesses & 0.226 & 0.738 & 0.030 \\
\hline 108 & $\begin{array}{l}\text { ATU } 550 \text { Bird, Horse and Princess (previously Search } \\
\text { for the Golden Bird) }\end{array}$ & 0.218 & 0.710 & 0.029 \\
\hline 7 & ATU 303 The Twins or Blood Brothers & 0.195 & 0.635 & 0.026 \\
\hline 111 & ATU 554 The Grateful Animals & 0.181 & 0.590 & 0.024 \\
\hline
\end{tabular}




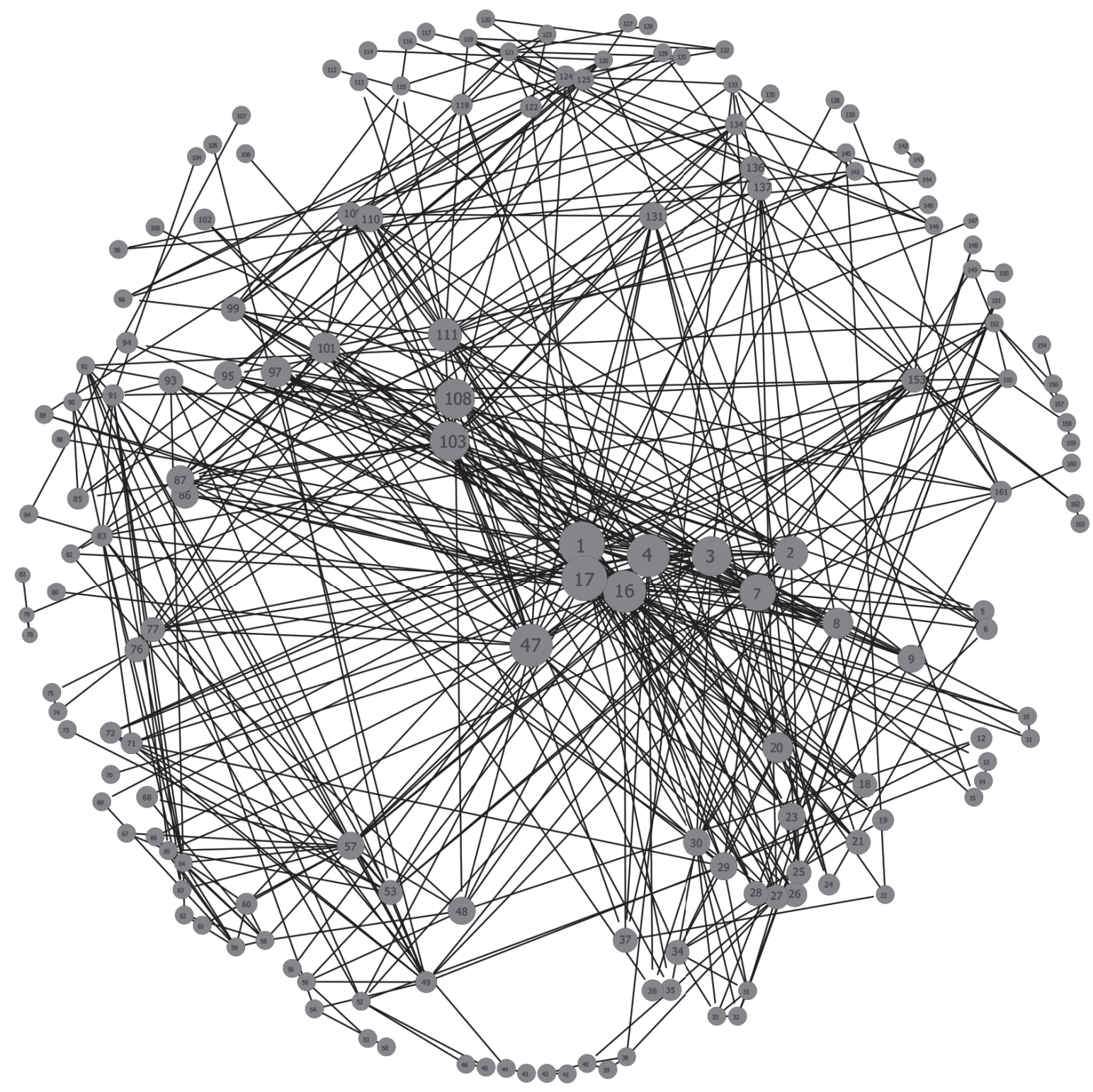

Figures $2 a$ and 2b. Radial (a) and on levels (b) by Eigenvector Centrality. 


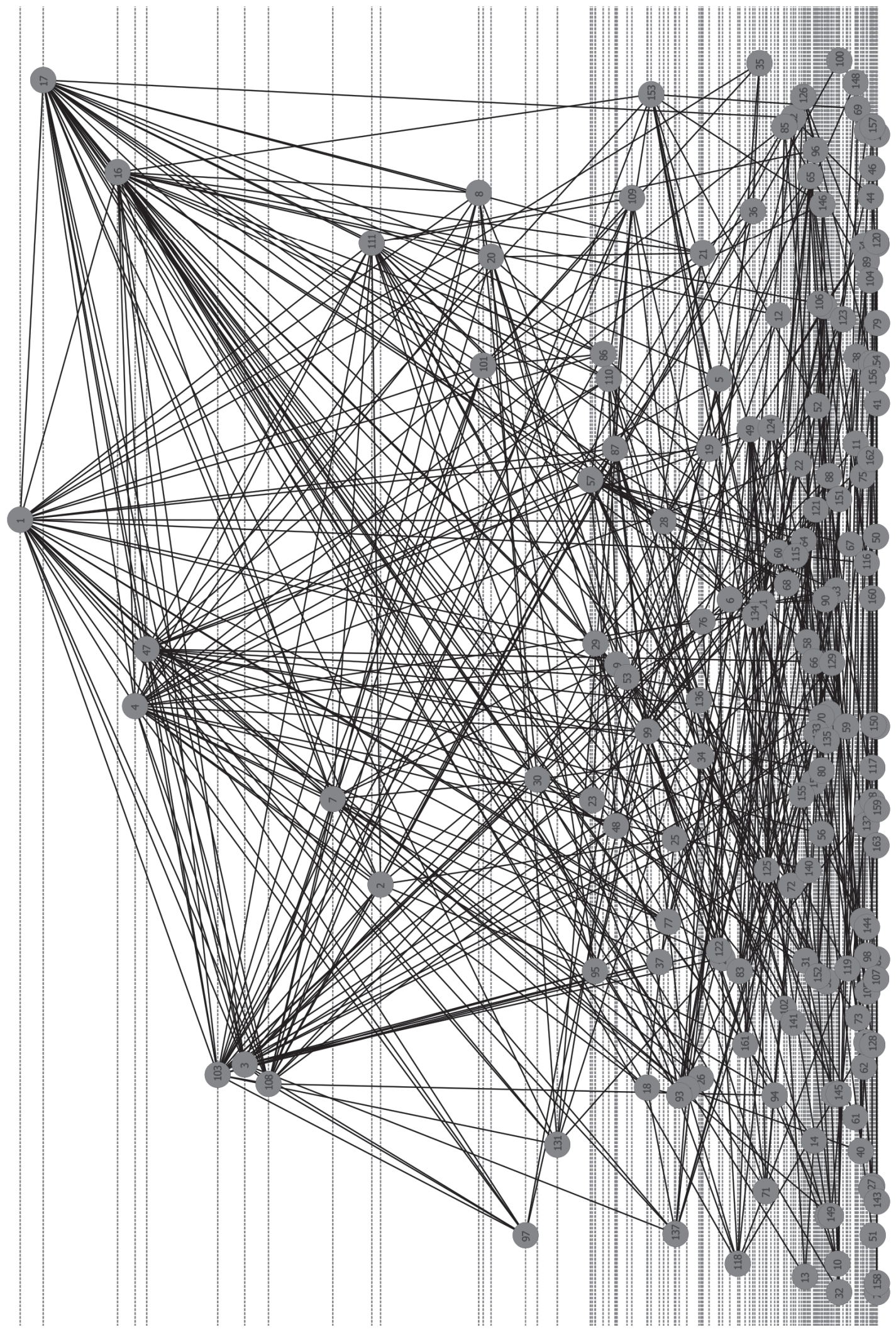


The Betweenness Centrality (BC) index of a node identifies its centrality on a graph based on the shortest path, i.e. the number of times a node acts as a bridge on the shortest path between two other nodes, and also represents the importance of a tale type in combination with other tale types. This measure allows us to test the hypothesis of a situation in which information travels through the whole network of ATU tale types along the shortest path identifying the most central narratives.

Table 3. ATU tale types with highest Betweenness Centrality scores.

\begin{tabular}{|l|l|l|l|}
\hline Node & Label & BC & BC' $^{\prime}$ \\
\hline 47 & ATU 400 The Man on a Quest for His Lost Wife & 1982.898 & 0.152 \\
\hline 16 & ATU 313 The Magic Flight & 1974.593 & 0.151 \\
\hline 17 & $\begin{array}{l}\text { ATU 314 Goldener (previously The Youth Transformed into a } \\
\text { Horse) }\end{array}$ & 1278.007 & 0.098 \\
\hline 57 & $\begin{array}{l}\text { ATU 425 The Search for the Lost Husband. This type refers to a } \\
\text { cycle of related tales. }\end{array}$ & 1153.732 & 0.088 \\
\hline 4 & ATU 302 The Ogre's (Devil's) Heart in the Egg & 1016.993 & 0.078 \\
\hline 1 & ATU 300 The Dragon Slayer & 986.798 & 0.076 \\
\hline 111 & ATU 554 The Grateful Animals & 941.974 & 0.072 \\
\hline 153 & $\begin{array}{l}\text { ATU 707 The Three Golden Children (previously The Three Golden } \\
\text { Sons) }\end{array}$ & 869.193 & 0.067 \\
\hline 27 & $\begin{array}{l}\text { ATU 326 The Youth Who Wanted to Learn What Fear Is } \\
\text { ATU 531 The Clever Horse (previously Ferdinand the True and } \\
\text { Ferdinand the False). This miscellaneous type comprises various } \\
\text { tales dealing with a clever horse. }\end{array}$ & 7747.930 & 0.059 \\
\hline 103 & 0.057 \\
\hline
\end{tabular}




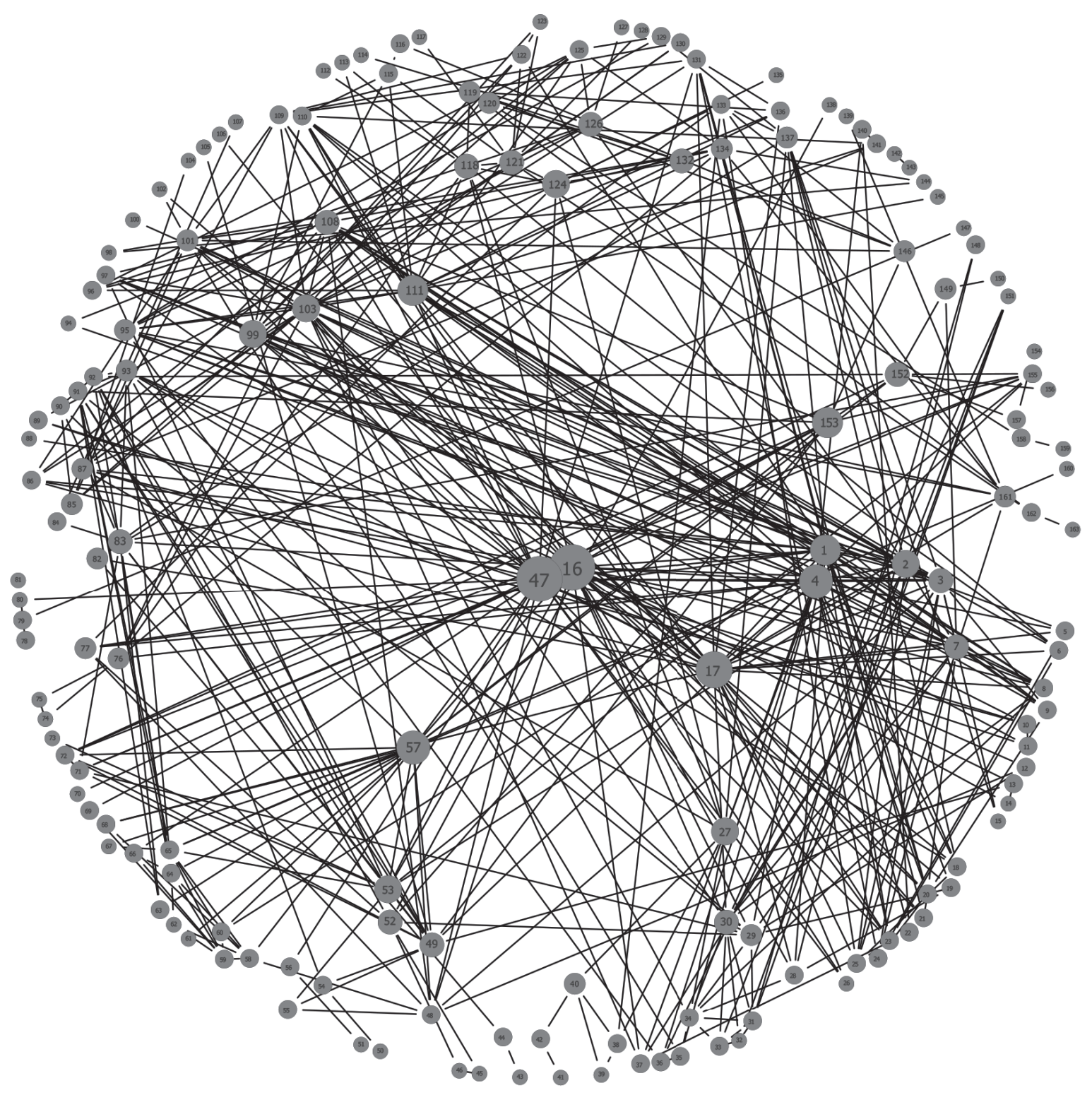

Figures $3 a$ and $3 b$. Radial (a) and on levels (b) by Betweenness Centrality. 


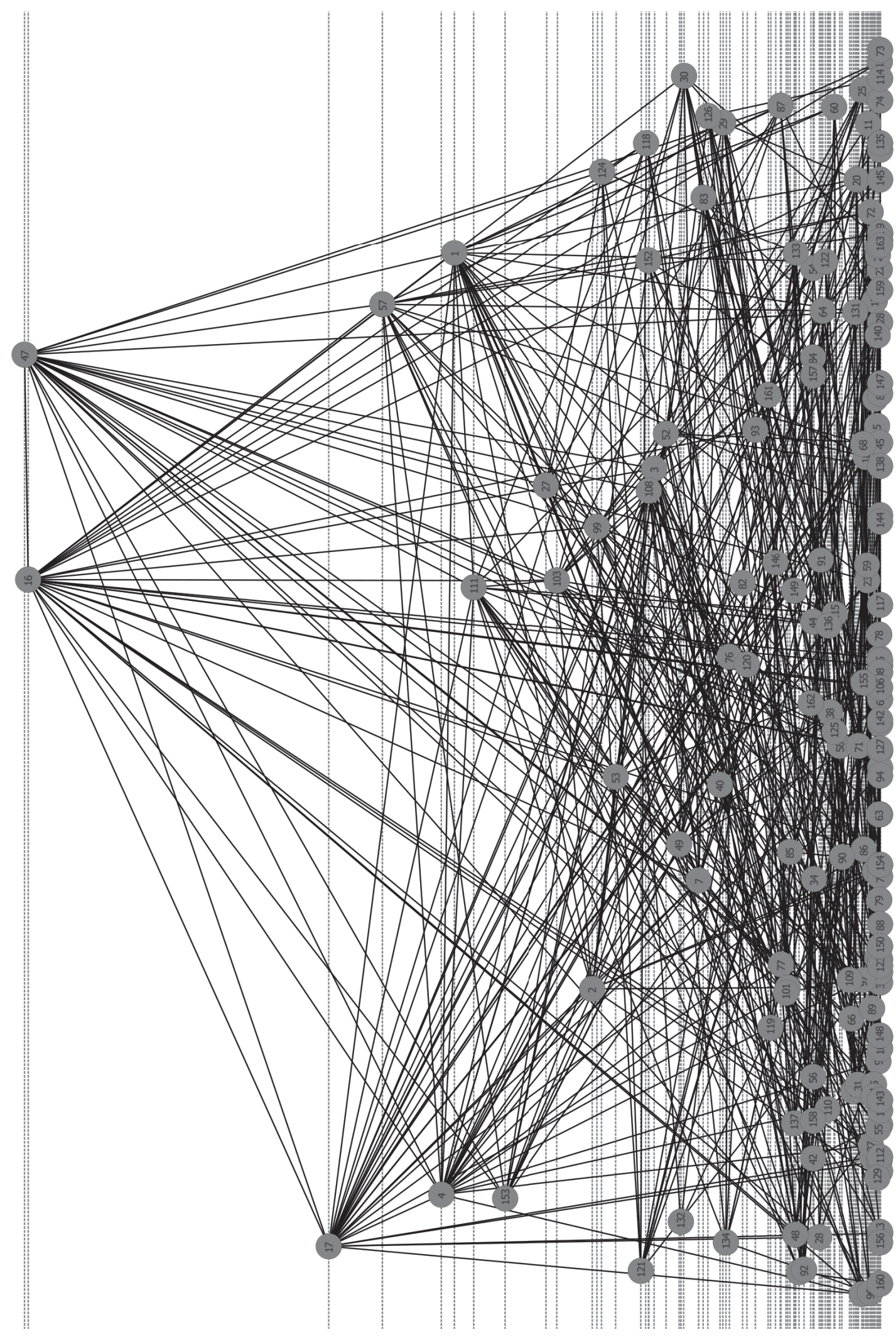

d'Huy: Folk-Tale Networks: A Statistical Approach to Combinations of Tale Types 
The synthesis of the results is summarised in Table 4 and will be discussed below.

Table 4. Synthesis: ATU tale types with highest Centrality scores.

\begin{tabular}{|c|c|c|c|c|}
\hline Node & Label & DC & EVC & BC \\
\hline 1 & ATU 300 The Dragon Slayer & $x$ & $x$ & $x$ \\
\hline 4 & ATU 302 The Ogre's (Devil's) Heart in the Egg & $x$ & $x$ & $x$ \\
\hline 17 & $\begin{array}{l}\text { ATU } 314 \text { Goldener (previously The Youth } \\
\text { Transformed into a Horse) }\end{array}$ & $x$ & $x$ & $x$ \\
\hline 16 & ATU 313 The Magic Flight & $x$ & $x$ & $x$ \\
\hline 47 & ATU 400 The Man on a Quest for His Lost Wife & $X$ & $X$ & $X$ \\
\hline 103 & $\begin{array}{l}\text { ATU } 531 \text { The Clever Horse (previously Ferdinand the } \\
\text { True and Ferdinand the False). This miscellaneous } \\
\text { type comprises various tales dealing with a clever } \\
\text { horse. }\end{array}$ & $x$ & $x$ & $x$ \\
\hline 111 & ATU 554 The Grateful Animals & $X$ & $X$ & $x$ \\
\hline 3 & ATU 301 The Three Stolen Princesses & $X$ & $X$ & \\
\hline 57 & $\begin{array}{l}\text { ATU } 425 \text { The Search for the Lost Husband. This type } \\
\text { refers to a cycle of related tales. }\end{array}$ & $x$ & & $X$ \\
\hline 108 & $\begin{array}{l}\text { ATU } 550 \text { Bird, Horse and Princess (previously Search } \\
\text { for the Golden Bird) }\end{array}$ & $x$ & $x$ & \\
\hline 7 & ATU 303 The Twins or Blood Brothers & & $X$ & \\
\hline 153 & $\begin{array}{l}\text { ATU } 707 \text { The Three Golden Children (previously The } \\
\text { Three Golden Sons) }\end{array}$ & & & $X$ \\
\hline
\end{tabular}

\section{Network Properties}

The average distance between two tale types - the distance between two vertices on a graph is the number of edges crossed when taking the shortest path - is 3.38774 . By way of comparison, and to give an example, the average distance within a graph independently made up of 163 vertices, generated by connecting vertices randomly using the Erdõs-Rényi method (model G [n, p]; edge probability: 0.05), is 2.1099 (Figure 4). The Erdõs-Rényi method is used to generate random graphs and to establish what it means for a property to hold for almost all graphs. A random graph with edge probability of 0.05 means a graph with a given number of vertices where for any two vertices the probability that there is an edge connecting them is $5 \%$ independently of the other edges. Conversely, within a regular circular Ring-Lattice graph with 163 vertices, where all vertices have 4 neighbours, this distance is 20.7531; with 6 neighbours, this distance is 14. A circular ring lattice is a regular network in a circular form where each node connects to all of its nearest neighbours with the same number of degrees. Such a graph forms a regular tilling, a perfect non-random network. The network formed by ATU tale types is therefore close to a randomly constructed network. 


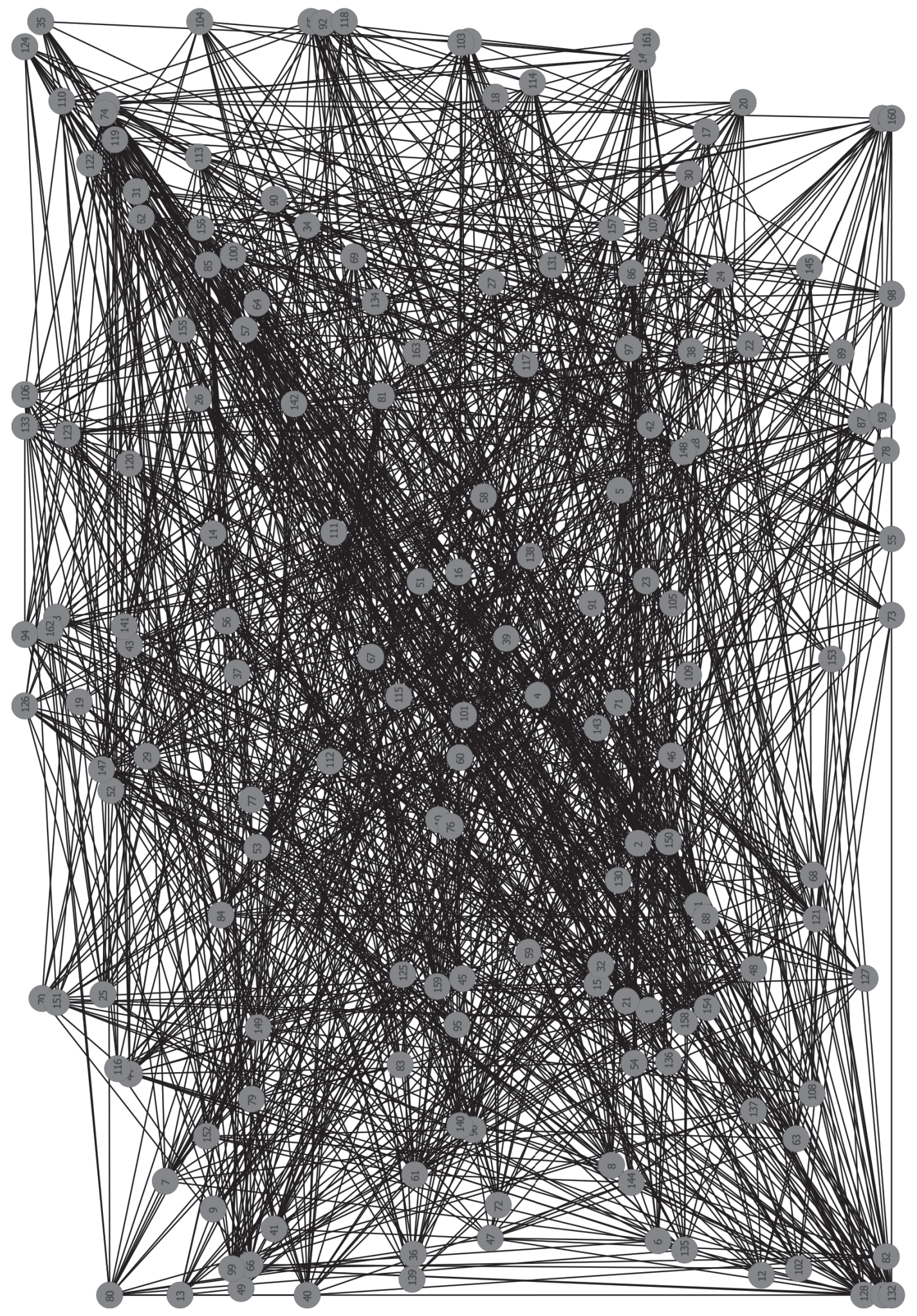

Figure 4. Random graph generated using the Erdõs-Rényi method. 
The local Clustering Coefficient (CLC), i.e. the likelihood of a node having neighbours that are also connected (Watts and Strogatz 1998), and the CLC', i.e. the adjusting value of the CLC to a notionally common scale, quantify how close each node and its neighbours are to being a complete subgraph. A score of 1 implies that each component of the network is a clique, i.e. a subset of vertices such that every two distinct vertices in the clique are adjacent. Here, the mean CLC is 0.671 (variance: DC: 80.082; EVC: 91.140; $B C: 102.198)$, this score indicating a high transitivity. Transitivity implies that if $a$ is connected with $b$ and $b$ is connected with $c$, then $c$ should be connected with $a$. The graph constructed using the Erdõs-Rényi method shows a low local clustering coefficient (0.1 with a variance of 0.399 ). The average local clustering coefficient obtained from the Ring-Lattice graph is closer to the results obtained from the tale type network $(d=4$ : 0.5 with a variance of $0.229 ; d=6: 0.6$ with a variance of 0.2290 ). The result shows that a lot of distinct ATU tale types in the complete graph are adjacent, i.e. are connected by an edge.

The 10 ATU tale types with the highest scores as calculated for each type of centrality - DC, EVC and BC (see Tables 1,2,3) - have been removed to observe the effects of their absence on the network. As a result, the average shortest path length (or number of mediating edges) between two ATU tale types calculated from the whole dataset (3.38774) increases between 26.16 and 29.92\% (DC: 4.35568, +28.57\%; EVC: 4.40144, $+29.92 \%$; BC: $4.27397,+26.16 \%$ ). According to these results, the ATU tale types with the highest scores represent points of failure in the network, their deletion leading to a dramatically increased average path length.

\section{Influence of 'Cultural Success' on the Centrality Measures}

Ara Norenzayan, with colleagues (2006), tried to determine the Grimm brothers' stories that had the greatest cultural success. Although this research focuses only on Grimm's stories, it concerns many of the tale types studied here. To obtain a measure of cultural popularity, Norenzayan et al. conducted searches of the World Wide Web in English and German, using Google. For each search, which included the exact title of each folk tale and the word "Grimm", the number of Web page 'hits' were counted as a rough indicator of cultural popularity. Norenzayan et al. then retained the most and the least culturally successful tales. All the stories with the greatest cultural success that were also present among the ATU index were retained for the current analysis: ATU 300 The Dragon-Slayer is represented in the collections of the Brothers Grimm under the name Die zwei Brüder (tale number 60); ATU 301 The Three Stolen Princesses, under the name Dat Erdmänneken (tale number 91); ATU 313 The Magic Flight, under the name Die Wassernixe (tale number 79); ATU 314 Goldener, under the name Iron Hans or Der Eisenhans (tale number 136); ATU 400 The Man on a Quest for His Lost Wife, under the name Der Trommler (tale number 194); ATU 425 The Search for the Lost Husband, under the name Das singende springende Löweneckerchen (tale number 88); ATU 531 The Clever Horse, under the name Ferenand getrü und Ferenand ungetrü (tale number 126); ATU 550 Bird, Horse and Princess, under the name Der goldene Vogel (tale number 57); ATU 554 The Grateful Animals, under the name Die treuen Thiere (tale number 104).

The centrality scores of these tale types have been calculated (Table 5). 
Table 5. Culturally successful fairy tales (according to Norenzayan et al. 2006).

\begin{tabular}{|c|c|c|c|c|c|}
\hline ATU & $\begin{array}{l}\text { Code } \\
\text { in the } \\
\text { current } \\
\text { paper }\end{array}$ & Name & $\begin{array}{l}\text { Degree of } \\
\text { Centrality } \\
\left(D^{\prime}\right)\end{array}$ & $\begin{array}{l}\text { Eigenvector } \\
\text { Centrality } \\
\left(E^{\prime \prime}\right)\end{array}$ & $\begin{array}{l}\text { Betweenness } \\
\text { Centrality } \\
\left(\mathrm{BC}^{\prime}\right)\end{array}$ \\
\hline 310 & 12 & The Maiden in the Tower & 0.025 & 0.005 & 0.000 \\
\hline $327 \mathrm{~A}$ & 29 & Hansel and Gretel & 0.080 & 0.013 & 0.028 \\
\hline 333 & 41 & Little Red Riding Hood & 0.012 & 0.000 & 0.000 \\
\hline 405 & - & Jorinde and Joringel & & & \\
\hline 410 & - & Sleeping Beauty & & & \\
\hline $425 \mathrm{C}$ & 60 & Beauty and the Beast & 0.037 & 0.005 & 0.008 \\
\hline 426 & - & $\begin{array}{l}\text { The Two Girls, the Bear and the } \\
\text { Dwarf }\end{array}$ & & & \\
\hline 440 & 67 & The Frog King & 0.019 & 0.001 & 0.000 \\
\hline 450 & 71 & Little Brother and Little Sister & 0.043 & 0.005 & 0.004 \\
\hline 461 & 76 & $\begin{array}{l}\text { Three Hairs from the Devil's } \\
\text { Beard }\end{array}$ & 0.049 & 0.008 & 0.027 \\
\hline 480 & 83 & The Kind and the Unkind Girl & 0.074 & 0.006 & 0.031 \\
\hline 500 & - & $\begin{array}{l}\text { The Name of the Supernatural } \\
\text { Helper }\end{array}$ & & & \\
\hline $510 \mathrm{~A}$ & 91 & Cinderella & 0.074 & 0.005 & 0.010 \\
\hline 533 & 105 & The Speaking Horsehead & 0.012 & 0.000 & 0.000 \\
\hline 555 & 112 & The Fisherman and His Wife & 0.012 & 0.000 & 0.000 \\
\hline 709 & 155 & Snow White & 0.049 & 0.004 & 0.003 \\
\hline
\end{tabular}

\section{Influence of Diffusion}

It is difficult to assess the influence of the geographic distribution of the tale types on their centrality score, since there are no specific studies for each of them. However, it is possible to use the Types of International Folk Tales if we do not forget that it is above all a tool to study the tale types. It can only give an idea of their distribution, i.e. country, region or language area where a tale type is spread (d'Huy et al. 2017).

To accept the following results, it is also necessary to consider that the biases in the identification of narrative areas are balanced for each of them, which prevents precise calculations.

The Types of International Folk Tales cannot tell whether a tale type is well known in an area. Nevertheless, as a general indicator the correlation between the centrality scores of a set of tale types - including both all tale types with a high centrality score, and the 'most successful' stories identified in Norenzayan et al. 2006 - on the one hand, and the number of cultural areas identified in Uther's book (2011) where each tale type is spread on the other hand, has been calculated (Table 6). The result shows a statistical trend with a high correlation between the dissemination of tale type and its centrality score. 
Table 6. Correlation between each centrality measure of a set of ATU tale types (i.e. all tale types with a high centrality score and the 'most successful' stories identified by Norenzayan et al. 2006: ATU 300, 301, 302, 303, 310, 313, 314, 327, 333, 400, 425, 425C, 440, 450, 461, 480, 510A, 531, $533,550,554,555,707,709)$ and the number of areas identified by Uther (2011).

\begin{tabular}{|l|l|l|l|l|}
\hline & DC' & EVC' $^{\prime}$ & EVC' $^{\prime}$ & BC' $^{\prime}$ \\
\hline Pearson & $\begin{array}{l}0,83371 \\
(p=4,2 E-07)\end{array}$ & $\begin{array}{l}0,80021 \\
(p=2,6775 E-06)\end{array}$ & $\begin{array}{l}0,79835 \\
(p=2,9377 E-06)\end{array}$ & $\begin{array}{l}0,66842 \\
(p=0,0003567)\end{array}$ \\
\hline Spearman & $\begin{array}{l}0,86816 \\
(p=3,8672 E-08)\end{array}$ & $\begin{array}{l}0,82514 \\
(p=6,9976 E-07)\end{array}$ & $\begin{array}{l}0,80886 \\
(1,7182 E-06)\end{array}$ & $\begin{array}{l}0,77065 \\
(p=1,0526 E-05)\end{array}$ \\
\hline
\end{tabular}

\section{DISCUSSION}

To begin, it is necessary to remember that a tale type is not a tale, but an abstract type with the purpose of subsuming stories that are similar. This is not a material reality, and a degree of arbitrariness exists in the definition. In addition, some versions may be misclassified, leading to possible errors. Finally, the definition of tale type is very broad. There are not only narrative types that describe narrative acts (such as ATU 300), but also collective narrative types that describe a general process, an overall structure, subsuming several tale types under a general type (such as ATU 400). Under these circumstances, the ATU classification system can only be used as a first step, since it is above all a research tool for systematising texts and secondary literature.

What does the network study of ATU tale types tell us? The properties of this network are in agreement with those identified for certain small world networks by Duncan J. Watts and Steven H. Strogatz (1998), with a small average shortest path length close to purely random graphs and a large clustering coefficient significantly higher than expected by random chance. In accordance with the hypothesis of a small world structure, the deletion of the most central ATU tale types causes a dramatic increase in mean shortest path length. This highlights the fact that some of the ATU tale types are more important than others in the mutual combinations, probably acting as a mental intermediary for storytellers between distinct groups of ATU tale type mainly connected inside smaller clusters. In other words, some typical stories act as 'highway junctions' between several large sets of folk tales. The study of such smaller clusters is beyond our scope, but provides some interesting research avenues for the future.

The influence of two factors (cultural success and diffusion area) on measures of centrality has been tested. It is significant to note that none of the most central tales determined in the present study are part of the list established in Norenzayan et al. 2006. This result allows us to rule out the thought that these high scoring tales could have been chosen to please an audience who were waiting for these tales like spectators waiting for a famous song at a concert. Indeed, if there had been such expectation it would have mechanically led to an increased number of connections of these famous tales with the other tales. Conversely, according to data from the same authors, many famous narratives such as Little Red Riding Hood have a low centrality score (Table 5). Only the dissemination of tale type (rather than cultural success) seems to be a determining factor, with a high value of Pearson and Spearman correlation between the number of cultural 
areas identified for each folk tale and their centrality. While the Pearson correlation coefficient is a measure of the linear correlation between two variables, $X$ and $Y$ (Pearson 1895), the Spearman correlation assesses monotonic relationships (whether linear or not) between the ranking of the two variables (Spearman 1904). For both coefficients, 1 shows a total positive correlation, 0 shows no linear correlation, and 1 shows total negative correlation between the two variables. The correlation explains between $45-75 \%$ of the variability of the database, so the most central tale types are also the most widely spread. The area of distribution of these later tale types is probably not due to their cultural success. If we accept the assumption that a widespread ATU tale type predates an isolated ATU tale type, following the assumption that the widespread form of a narrative is older than its rare form (Propp 1928), it is also theoretically possible that the most central ATU tale types have survived since antiquity. This makes it possible to propose a correlation between the centrality of ATU, their spread and their assumed age.

The great age of folk tales with a high centrality score is only an explanatory hypothesis. However, for the majority of the seven tale types with the highest centrality scores, it must be noted that other clues also point in this direction (see also d'Huy 2018 for similar results on the Clever Fox tale types).

Three different approaches (areal, structural and phylogenetic) have shown the great antiquity of ATU 300 The Dragon-Slayer. Yuri Berezkin (2013-2014) uses areal diffusion to show the Paleolithic and Eurasian origin of the fight against the "dragon". The great age of the motif of the fight between a thunder god and a "dragon" is also highlighted by Joseph Fontenrose (1980), who notices that distribution covers the whole of the northern hemisphere, whereas Michael Witzel $(2008 ; 2012)$ makes a similar observation concerning the more general motif of the fight between the hero and the mythological snake. Kurt Ranke (1934) also showed the great antiquity of Eurasiatic ATU 300 and 303, even if Ranke reached no precise conclusion as to the age of these types. Using a structural approach to compare Lithuanian and Belarusian myths, which are among the most conservative, Viačeslav Ivanov and Vladimir Toporov (1970) demonstrate the great Indo-European antiquity of the fight between the storm god and the dragon. Finally, phylogenetic analysis also reconstructs the motif of the fight against the dragon during the Eurasiatic Paleolithic period (d'Huy 2014; 2016a). The phylogenetic method is based on the idea that the more two cultural traditions or two versions of the same folk tale/myth are similar, the more recent the date of their divergence. This assumption makes it possible to build evolutionary trees and, based on the structure of these trees, to reconstruct the first forms of traditions and tales. This is of course a quick summary, for example borrowing is also taken into account, and the results obtained are compared with those obtained using the same methods from other corpora, or using radically different approaches (d'Huy 2012; 2016b; Le Quellec 2015; d'Huy and Berezkin 2017; Le Quellec and d'Huy 2017).

About the ATU 302 The Ogre's (Devil's) Heart in the Egg, James George Frazer (1913: 95-132) shows the worldwide diffusion of the belief that a man's soul or heart may be deposited for safety outside of his body, and that so long as it remains intact there, the person is invulnerable and immortal. According to the view of this tale type as Palaeolithic, Andrei Korotayev and Daria Khaltourina (2011) demonstrate that the motif of Invulnerability Except in One Spot: Unique External Soul belonged to a set of myths concentrated in southern Siberia and in the north-eastern part of Central Asia, as well as 
in northern America (with a lesser distribution in southern America). The distribution of this set of myths shows a significant statistical correlation in Eurasia, Oceania and America, to the distribution of mitochondrial DNA C (between 10 and 14.5\% of the variance explained). Haplogroup $\mathrm{C}$ would have appeared in Central Asia approximately 24,000 years ago, and the start of later diffusion of this haplogroup could also be related to the spread of the tale.

In agreement with Berezkin (2013: 162-165), the worldwide diffusion of the main motifs of ATU 313 The Magic Flight (i.e. D671 or D672 according to the classification of Thompson 1956) and their absence in Australia and Melanesia suggests a Palaeolithic diffusion, yet older than the out of Africa period. This motif is already mentioned by Franz Boas (1914: 384-386) as one of the proofs of transmission of tales from the Old to the New World; Gudmund Hatt (1949: 92-94) regards as certain the fact that the 'magic flight' spread beginning in the Pre-Columbian period from Asia to America.

Claude Lévi-Strauss (1995 [1991]: 182) notes the similarities between ATU 314 Goldener (more precisely Scurfy John), the widespread north-amerindian story of the Lynx that "belongs to the most authentic part of Amerindian patrimony", and an even closer Aztec legend. He concludes that ancient diffusion was probable, "even though we are able to reconstitute neither their itineraries nor their chronology" (ibid.: 185). Given the necessity for contact to conduct such a transmission, the tale must go back at least to the first settlement of America.

A Paleolithic form of one of the three different types of ATU 400 The Man on a Quest for His Lost Wife (namely the Swan Maiden) has been reconstructed using arealogical (Berezkin 2010) and phylogenetic (d'Huy 2016c) analyses. The tale probably appears in South East or East Asia. Moreover, according to Hatt (1949: 94-96, 107), the motif probably spread from Asia to America through the North Pacific region.

To my knowledge, there are no studies assessing the age and the origin of ATU 554 The Grateful Animals. The fact that it is known in Mesoamerica (Peñalosa 1996: 66) and is widespread in North America (Thompson 1929: Note 46), like ATU 314, may points toward the great antiquity of the tale, but nothing could be less certain and it could be independent inventions or later diffusion. It is also difficult to evaluate the antiquity of ATU 531 The Clever Horse, because this miscellaneous type comprises various tales dealing with a clever horse.

Despite these limitations, 5 of the 7 tales are probably Palaeolithic and it is remarkable that a number of these very ancient stories were preserved in under the shape of central fairy tales. This paper is not the place to take sides about the reasons for the longevity and popularity of these tales, yet it may provide some insight on this question, including the choice of the ATU tale types to study. Various avenues of reflection have already been opened up concerning, for example, the effect of minimally counterintuitive cognitive template that includes mainly intuitive concepts combined with a minority of counterintuitive ones (e.g. Barrett 2000; Norenzayan et al. 2006) or the role of emotion and how it enhances formation and retrieval of memory via the activation of certain neuromodulators (d'Huy 2013).

A possible limitation of this paper is the presence among the results of miscellaneous or heterogeneous tale types, for example ATU 400 or ATU 531, which merge episodes with different areal distributions; this classification may give an undue advantage to some types. However, this hypothesis is impossible to check with the ATU database 
in its current form and case studies are essential to provide a better understanding of the relations between folk tales. Another possible limitation of this study is that it only considers fairy tale types. Taking into account the combinations of tales of different categories could help reduce or increase the centrality of some of them. In the preface to Roger Pinon's book Le Conte merveilleux comme sujet d'études (1955), Paul Delarue wrote that "we still lack in-depth studies on phenomena that have played a role in the life of the story: contamination for example" (ref. by Ténèze 1958: 297), which leads MarieLouise Ténèze (1958: 298) to note that

the continuation of Paul Delarue's Catalogue will bring valuable elements to such a study; as would be the case now, for those who would try to collect them, many passages from his annotated editions, examples of contamination at different levels, either by junction pattern or by thematic analogy.

Further research is also required to assess the influence of each of these different levels.

\section{NOTES}

1 Correspondance: $1 / 300 ; 2 / 300 A ; 3 / 301 ; 4 / 302 ; 5 / 302 B ; 6 / 302 C^{*} ; 7 / 303 ; 8 / 303 A ; 9 / 304 ; 10 /$ 306; 11/ 307; 12/ 310; 13/ 311; 14/ 312; 15/312D; 16/ 313; 17/ 314; 18/ 314A; 19/314A*; 20/ 315; 21/ $315 \mathrm{~A} ; 22 / 316 ; 23 / 317 ; 24 / 318 ; 25 / 321 ; 26 / 325 ; 27 / 326 ; 28 / 327 ; 29 / 327 \mathrm{~A} ; 30 / 327 \mathrm{~B} ; 31 / 327 \mathrm{C} ; 32 /$ 327F; 33/ 327G; 34/ 328; 35/ 328*; 36/ 328A*; 37/ 329; 38/ 330; 39/ 331; 40/ 332; 41/ 333; 42/ 334; 43/ 360; 44/ 361; 45/363; 46/ 365; 47/ 400; 48/ 402; 49/ 403; 50/ 403C; 51/ 404; 51/ 407; 53/ 408; 54/ 409; 55/ 409A; 56/ 412; 57/ 425; 58/ 425A; 59/ 425B; 60/ 425C; 61/ 425D; 62/ 425E; 63/ 431; 64/ 432; 65/ 433B; 66/ 434; 67/ 440; 68/ 441; 69/ 442; 70/ 449; 71/ 450; 72/ 451; 73/ 452B*; 74/ 460A; 75/ 460B; 76/ 461; 77/ 465; 78/ 470; 79/ 470A; 80/ 470B; 81/ 471; 82/ 475; 83/ 480; 84/ 480A; 85/ 501; 86/ 502; 87/ 505; 88/ 506*; 89/ 507; 90/ 510; 91/ 510A; 92/ 510B; 93/ 511; 94/ 513; 95/ 513A; 96/ 513B; 97/ 516; 98/ 517; 99/ $518 ; 100 / 519 ; 101 / 530 ; 102 / 530 \mathrm{~A} ; 103 / 531 ; 104 / 532 *$; 105/ 533; 106/ 537; 107/ 545A; 108/ 550; 109/ 551; 110/ 552; 111/ 554; 112/ 555; 113/ 556F*; 114/ 559; 115/ 560; 116/ 561; 117/ 562; 118/ 563; 119/ $564 ; 120 / 565 ; 121 / 566 ; 122 / 567 ; 123 / 567 \mathrm{~A} ; 124 / 569 ; 125 / 570 ; 126 / 571 ; 127 / 571 B ; 128 / 575 ; 129 /$ 577; 130/ 580; 131/ 590; 132/ 591; 133/ 592; 134/ 610; 135/ 611; 136/ 613; 137/ 650A; 138/ 652; 139/ 655; 140/ 665; 141/ 667; 142/ 670; 143/ 670A; 144/ 671; 145/ 673; 146/ 675; 147/ 681; 148/ 700; 149/ 705A; 150/ 705A*; 151/ 705B; 152/ 706; 153/ 707; 154/ 708; 155/ 709; 156/ 710; 157/ 713; 158/ 715; 159/ 715A; 160/ 720; 161/ 725; 162/ 735; 163/ 735A.

\section{REFERENCES}

Barrett, Justin. 2000. Exploring the Natural Foundations of Religion. - Trends in Cognitive Science 4 (1): 29-34. DOI: https://doi.org/10.1016/S1364-6613(99)01419-9.

Berezkin, Yuri E. 2010. Sky-Maiden and World Mythology. - Iris 31: 27-39.

Berezkin, Yuriy Yevgen'yevich. 2013. Afrika, migratsii, mifologiya: Arealy rasprostraneniya fol'klornykh motivov v istoricheskoy perspektive. Sankt-Peterburg: Nauka. [Березкин, Юрий Евгеньевич. 2013. Африка, миграциии, мифология: Ареаль распространения фольклорных мотивов в исторической перспективе. Санкт-Петербург: Наука.]

Berezkin, Yuri E. 2013-2014. Serpent that Closes Sources of Water and Serpent that Devours Nestlings of Giant Bird: Assessment of the Age of the Dragon-Fighting Myths in Eurasia. - Armenian Journal of Near Eastern Studies 8 (1-2): 178-185. 
Boas, Franz. 1914. Mythology and Folk-Tales of the North American Indians. - Journal of American Folklore 27 (106): 374-410. DOI: https://doi.org/10.2307/534740.

Bonacich, Phillip. 1972. Factoring and Weighting Approaches to Status Score and Clique Identification. - The Journal of Mathematical Sociology 2 (1): 113-120. DOI: https://doi.org/10.1080/00 22250X.1972.9989806.

Fischer, John L. and Max Lüthi. 1977. Assoziation - Enzyklopädie des Märchens 1. Aarne - Bayerischer Hiasl, edited by Kurt Ranke, Hermann Bausinger, Wolfgang Brückner, Max Lüthi, Lutz Röhrich and Rudolf Schenda. Berlin; New York, NY: De Gruyter, 903-912.

Fontenrose, Joseph. 1980. Python: A Study of Delphic Myth and its Origins. Berkeley, CA; Los Angeles, CA; London: University of California Press.

Frazer, James George. 1913. Balder the Beautiful: The Fire-Festivals of Europe and the Doctrine of the External Soul. UK; USA; Canada: Macmillan and Co.

Hatt, Gudmund. 1949. Asiatic Influences in American Folklore. København: I kommission hos ejnar Munksgaard.

d'Huy, Julien. 2012. Un ours dans les étoiles: recherche phylogénétique sur un mythe préhistorique. - Préhistoire du Sud-Ouest 20 (1): 91-106.

d'Huy, Julien. 2013. Rôle de l'émotion dans la mémorisation des contes et des mythes. - Mythologie française 253: 21-23.

d'Huy, Julien. 2014. Mythologie et statistique: reconstruction, évolution et origines paléolithiques du combat contre le dragon. - Mythologie française 256: 17-23.

d'Huy, Julien. 2016a. Première reconstruction statistique d'un rituel paléolithique. - Nouvelle Mythologie Comparée / New Comparative Mythology 3: 15-47.

d'Huy, Julien. 2016b. The Evolution of Myths. - Scientific American 315 (6): 62-69. DOI: https://doi. org/10.1038/scientificamerican1216-62.

d'Huy, Julien. 2016c. Le motif de la femme-oiseau (T111.2.) et ses origines paléolithiques. Mythologie française 265: 4-11.

d'Huy, Julien. 2018. Le Web du Goupil. - Mythologie française 271: 15-19.

d'Huy, Julien and Yuri E. Berezkin. 2017. How Did the First Humans Perceive the Starry Night? On the Pleiades. - The Retrospective Methods Network Newsletter 12-13: 100-122.

d'Huy, Julien; Jean-Loïc Le Quellec, Yuri Berezkin, Patrice Lajoye and Hans-Jörg Uther. 2017. Studying Folktale Diffusion Needs Unbiased Dataset. - Proceedings of the National Academy of Sciences of the United States of America 114 (41): E8555. DOI: https://doi.org/10.1073/ pnas.1714884114.

Ivanov, Vjačeslav V. and Vladimir Toporov. 1970. Le mythe indo-européen du dieu de l'orage poursuivant le serpent: reconstruction du schéma - Échanges et communications: mélanges offerts à Claude Lévi-Strauss, edited by Jean Pouillon. Paris; La Haye: Mouton, 1180-1206.

Karsdorp, Folgert and Antal van den Bosch. 2016. The Structure and Evolution of Story Networks. - Open Science 3 (6). DOI: https://doi.org/10.1098/rsos.160071.

Kalamaras, Dimitris. 2017. Social Network Visualizer (SocNetV). Social network analysis and visualization software. http://socnetv.org (accessed March 2, 2019).

Korotayev, Andrey Vital'yevich; Dar'ya Andreyevna Khalturina and Yuriy Yevgen'yevich Berezkin. 2011. Mify i geny: Glubokaya istoricheskaya rekonstruktsiya. Moskva: Librokom. [Коротаев, Андрей Витальевич, Дарья Андреевна Халтурина, Юрий Евгеньевич Березкин. 2011. Мифы и гень: Глубокая историческая реконструкция. Москва: АИБРОКОМ.]

Le Quellec, Jean-Loïc. 2015. En Afrique, pourquoi meurt-on? Essai sur l'histoire d'un mythe africain. - Afriques. https://journals.openedition.org/afriques/1717 (accessed March 2, 2019).

Le Quellec, Jean-Loïc and Julien d'Huy. 2017. Géranomachie: aréologie et phénétique. - Hommages à Bernard Sergent, edited by Alain Meurant. Paris: L'Harmattan, 282-308.

Lévi-Strauss, Claude. 1995 [1991]. The Story of Lynx, translated by Catherine Tihanyi. Chicago, IL; London: The University of Chicago Press. 
Luzel, François-Marie. 1887. Contes populaires de Basse Bretagne. Paris: Maisonneuve et Ch. Leclerc.

Mac Carron, Padraig and Ralph Kenna. 2012. Universal properties of mythological networks. Europhysics Letters 99 (2). DOI: https://doi.org/10.1209/0295-5075/99/28002.

Norenzayan, Ara; Scott Atran, Jason Faulkner and Mark Schaller. 2006. Memory and Mystery: The Cultural Selection of Minimally Counterintuitive Narratives. - Cognitive Science 30 (3): 531-553. DOI: https://doi.org/10.1207/s15516709cog0000_68.

Pearson, Karl. 1895. Note on Regression and Inheritance in the Case of Two Parents. - Proceedings of the Royal Society of London 58: 240-242. DOI: https://doi.org/10.1098/rspl.1895.0041.

Peñalosa, Fernando. 1996. El cuento popular maya: una introducción. Rancho Palos Verdes: Yax Te.

Pinon, Roger. 1955. Le Conte merveilleux comme sujet d'études. Liège: Centre d'éducation populaire et de culture.

Propp, Vladimir Yakovlevich. 1928. Morfologiya skazki. Leningrad: Academia. [Пропп, Владимир Яковлевич. 1928. Морфология сказки. Ленинград: Academia.]

Ranke, Kurt. 1934. Die zwei Brüder: Eine Studie zur vergleichenden Märchenforschung. Helsinki: Suomalainen Tiedeakatemia.

Röhrich, Luz. 1976. Sage und Märchen: Erzählforschung heute. Freiburg; Basel; Wien: Herder.

Shojaei Kawan, Christine. 1996. Kontamination. - Enzyklopädie des Märchens 8: Klerus - Maggio, edited by Kurt Ranke, Hermann Bausinger, Wolfgang Brückner, Max Lüthi, Lutz Röhrich and Rudolf Schenda. Berlin; New York, NY: De Gruyter, 210-217.

Spearman, Charles. 1904. The Proof and Measurement of Association between Two Things. American Journal of Psychology 15 (1): 72-101. DOI: https://doi.org/10.2307/1412159.

Ténèze, Marie-Louise. 1958. Une contribution fondamentale à l'étude du folklore français: le conte populaire français. Catalogue raisonné des versions de France et des pays de langue française d'outre-mer, Tome I. - Arts et Traditions populaires 6 (3-4): 289-303.

Thompson, Stith. 1929. Tales of the North American Indians. Cambridge, MA: Harvard University Press.

Thompson, Stith. 1956. Motif-index of Folk-literature vol. 2, D-E. Bloomington, IN: Indiana University Press.

Uther, Hans-Jörg. 2011. The Types of International Folk-Tales: A Classification and Bibliography. Part 1: Animals Tales, Tales of Magic, Religious Tales, and Realistic Tales, with an Introduction. Helsinki: Academia Scientiarum Fennica.

Voigt, Vilmos. 1977. Affinität. - Enzyklopädie des Märchens 1: Aarne - Bayerischer Hiasl, edited by Kurt Ranke, Hermann Bausinger, Wolfgang Brückner, Max Lüthi, Lutz Röhrich and Rudolf Schenda. Berlin; New York, NY: De Gruyter, 154.

Watts, Duncan J. and Steven H. Strogatz. 1998. Collective Dynamics of 'Small World' Networks. - Nature 393 (6684): 440-442. DOI: https://doi.org/10.1038/30918.

Witzel, Michael. 2008. Slaying the Dragon across Eurasia. - Hot Pursuit of Language in Prehistory: Essays in the Four Fields of Anthropology, edited by John D. Bengston. Amsterdam; Philadelphia, PA: John Benjamins Publishing Company, 263-286. DOI: https://doi.org/10.1075/z.145.21wit. Witzel, Michael. 2012. The Origins of the World's Mythologies. Oxford: Oxford University Press. 